\title{
Substitution of ovarian function in the pregnant rat
}

\author{
S. J. Mantalenakis \\ Department of Obstetrics and Gynaecology, \\ Tzanion General Hospital, Piraeus, Greece
}

In the rat, bilateral ovariectomy performed during the first 4 days of pregnancy results in inhibition of implantation, while spaying after mid-gestation induces abortion or resorption of the fetuses (Haterius, 1936; Courrier \& Cologne, 1950). Daily injections of progesterone have been reported to maintain pregnancy in ovariectomized rats (Stucki, 1958; Talwalker, Krahenbuhl, \& Desaulles, 1966), but it is possible that oestrogen is also necessary, as suggested by Nutting \& Meyer (1964) and Dickmann \& Hart (1972). The present study was designed not only to re-examine the above findings, but also to investigate the role of the ovary throughout pregnancy using the technique of egg transfer. Ovariectomized female rats were made pseudopregnant by injections of oestrogen and/or progesterone and then pregnant by egg transplantation. High rates of pregnancies continuing to term were interpreted as an indication of the proper treatment.

Mature virgin females, weighing 200-240 g, of the Sprague-Dawley strain were anaesthetized with ether and bilaterally ovariectomized during oestrus by a dorsolateral approach. The operated animals were allocated to groups according to the hormonal treatment which was begun immediately after ovariectomy. The doses of progesterone and oestrone shown in Table 1 were injected s.c. in $0.2 \mathrm{ml}$ sesame oil. To obtain blastocysts for transfer, normally cyclic rats were placed overnight with fertile males. Insemination was confirmed the next morning before 10.00 hours and the day on which spermatozoa were found in the vaginal smear was designated Day 1 of pregnancy. Blastocysts were collected from uterine horns of rats killed between 09.00 and 12.00 hours on Day 5, and 7-9 blastocysts were transferred into the left horn of the recipient 5 days after ovariectomy and start of the treatment. Details of the egg transfer technique have been reported elsewhere (Mantalenakis \& Ketchel, 1966). A laparotomy under ether anaesthesia was performed 5 days Iater (Day 10 of pregnancy) and the number of implantations was counted. The incision was closed and the animal allowed to recover. On Day 22 the number of live young in the uterus was recorded at Caesarean section, because even with the hormonal treatment parturition would not have occurred.

The results relating to the induction of implantation and maintenance of pregnancy during the first 10 days are summarized in Table 1. Progesterone alone (Group 1) was unable to permit implantation, but a high implantation rate occurred in rats in the other two groups and in intact pseudopregnant controls. The results regarding the maintenance of pregnancy from Day 10 to Day 22 are shown in Table 1. Animals in Groups 5, 6, and 7 were treated in the same way as those in Group 3 for the first 9 days. Maintenance of the implantations was low when progesterone alone was given from Day 10 to Day 22 (Groups 5 and 6), but a combination of progesterone and oestrone (Group 7) resulted in a high survival rate, similar to that obtained in the pseudopregnant controls.

The results are in agreement with previous observations which suggest that successful implantation depends not only on the presence of progesterone, but also on that of oestrogen, particularly during the afternoon of Day 4. The administration of a small quantity of oestrone during the first half of pregnancy does not act deleteriously on embryonic development and appears to be essential for survival of fetuses in later pregnancy. In the second half of gestation, the placenta of the rat secretes luteotrophin which in turn stimulates progesterone secretion by the corpora lutea (Yoshinaga \& Adams, 1967). Oestrogens are reported to be present in the peripheral plasma during pregnancy in rats (Shaikh, 1971) and in mice (McCormack \& Greenwald, 1974), although no oestrogenic activity was found in mouse placentae (Harkness, McLaren \& Roy, 1964). It is possible therefore, that the ovary of the rat is also the source of a small quantity of oestrogen which acts synergistically with progesterone to maintain normal pregnancy. 
Table 1. Induction of implantation and maintenance of pregnancy in ovariectomized rats after hormonal treatment and egg transfer

\begin{tabular}{|c|c|c|c|c|c|c|c|}
\hline Group & Treatment* & $\begin{array}{l}\text { No. of } \\
\text { eggs } \\
\text { trans- i } \\
\text { ferred } \\
\text { on Day } 5\end{array}$ & $\begin{array}{c}\text { No. of } \\
\text { implantations } \\
\text { on } \\
\text { Day } 10(\%)\end{array}$ & $\begin{array}{c}\text { No. of } \\
\text { live young } \\
\text { on } \\
\text { Day } 22(\%)\end{array}$ & $\begin{array}{l}\text { No. of } \\
\text { animals } \\
\text { receiv- } \\
\text { ing } \\
\text { eggs }\end{array}$ & $\begin{array}{l}\text { No. with } \\
\text { implant- } \\
\text { ations on } \\
\text { Day } 10(\%)\end{array}$ & $\begin{array}{l}\text { No. with } \\
\text { young on } \\
\text { Day } 22(\%)\end{array}$ \\
\hline 1 & $4 \mathrm{mg}$ progesterone, Days $1-9$ & 117 & $0(0)$ & - & 14 & $0(0)$ & - \\
\hline 2 & $\begin{array}{c}4 \mathrm{mg} \text { progesterone }+2 \mu \mathrm{g} \\
\text { oestrone, Days } 1-9\end{array}$ & 109 & $69(63 \cdot 3)$ & - & 13 & $11(84 \cdot 6)$ & - \\
\hline 3 & $\begin{array}{l}4 \text { mg progesterone, Days } 1-9+ \\
2 \mu \text { gestrone at } 14.00 \text { hours, } \\
\text { Day } 4\end{array}$ & 102 & $70(68 \cdot 6)$ & - & 12 & $11(41 \cdot 7)$ & - \\
\hline 4 & $\begin{array}{l}\text { Control (pseudopregnant by } \\
\text { sterile mating) }\end{array}$ & 112 & $81(72 \cdot 3)$ & - & 14 & $13(92 \cdot 8)$ & - \\
\hline 5 & $\begin{array}{l}\text { As for Group } 3+4 \mathrm{mg} \\
\text { progesterone, Days 10-21 }\end{array}$ & 73 & $58(79 \cdot 2)$ & $9(15.9)$ & 11 & $10(90.9)$ & $2(20)$ \\
\hline 6 & $\begin{array}{l}\text { As for Group } 3+8 \mathrm{mg} \\
\text { progesterone, Days 10-21 }\end{array}$ & 91 & $70(77 \cdot 7)$ & $16(22 \cdot 8)$ & 12 & $11(90 \cdot 1)$ & $4(36 \cdot 4)$ \\
\hline 7 & $\begin{array}{l}\text { As for Group } 3+4 \mathrm{mg} \\
\text { progesterone }+2 \mu \mathrm{g} \text { oestrone, } \\
\text { Days } 10-21\end{array}$ & 102 & $83(81 \cdot 3)$ & $55(66 \cdot 2)$ & 13 & $12(92 \cdot 3)$ & $11(91 \cdot 7)$ \\
\hline 8 & $\begin{array}{l}\text { Control (pseudopregnant by } \\
\text { sterile mating) }\end{array}$ & 119 & $92(76 \cdot 6)$ & $68(73.9)$ & 15 & $14(93 \cdot 3)$ & $13(94 \cdot 3)$ \\
\hline
\end{tabular}

* There was no treatment after Day 9 of the animals in Groups 1-3.

\section{References}

Courrier, R. \& Cologne, R.A. (1950) L'equilibre hormonal en rattes au cours de la gestation. $C . r$. hebd. Séanc. Acad. Sci., Paris 230, 1338-1441.

DickmanN, Z. \& HART, J.R. (1972) The significance of daily administration of progesterone and oestrogen for the maintenance of pregnancy in ovariectomized rats. Endocrinology 90, 1667-1669.

Harkness, R.A., Mclaren, A. \& Roy, E.J. (1964) Oestrogens in mouse placentae. $J$. Reprod Fert. 8, $411-414$.

Haterius, H.O. (1936) Reduction of litter size and maintenance of pregnancy in the oophorectomized rat: evidence concerning the endocrine rôle of the placenta. Am. J. Physiol. 114, 399-406.

Mantalenakis, S.J. \& Ketchel, M.M. (1966) Pseudopregnant recipients for blastocyst transfer in rats. Int. J. Fert. 11, 318-321.

McCormack, J.T. \& Greenwald, G.S. (1974) Pro* gesterone and oestradiol-17 $\beta$ concentration in the peripheral plasma during pregnancy in the mouse. J. Endocr. 62, 101-107.

NutTing, E.F. \& MeYeR, R.K. (1964) Effects of various steroids on nidation and fetal survival in ovariectomized rats. Endocrinology 74, 573-577.

ShaikH, A.A. (1971) Estrone and estradiol levels in the ovarian venous blood from rats during the estrous cycle and pregnancy. Biol. Reprod. 5, 297-307.

STUCKI, J.C. (1958) Maintenance of pregnancy in ovariectomized rats with some newer progestins. Proc. Soc. exp. Biol. Med. 99, 500-504.

Talwalker, P.K., Krahenbuhl, C. \& Desaulles, P.A. (1966) Maintenance of pregnancy in spayed rats with $20 \alpha$-hydroxypregn-4-ene-3-one and $20 \beta$ hydroxypregn-4-ene-3-one. Nature, Lond. 209, 8687.

YoshinagA, K. \& ADAMS, C.E. (1967) Luteotrophic activity of the young conceptus in the rat. J. Reprod. Fert. 13, 505-509.

Received 30 December 1975 